\title{
Variability of CP4 EPSPS expression in genetically engineered soybean (Glycine max L. Merrill)
}

\author{
Parimala Chinnadurai • Duška Stojšin • Kang Liu • Gregory E. Frierdich • \\ Kevin C. Glenn · Tao Geng • Adam Schapaugh • Keguo Huang • \\ Andrew E. Deffenbaugh (i) $\cdot$ Zi L. Liu $\cdot$ Luis A. Burzio
}

Received: 29 May 2018/Accepted: 24 August 2018/Published online: 1 September 2018

(C) The Author(s) 2018

\begin{abstract}
The expression of the CP4 EPSPS protein in genetically engineered (GE) soybean confers tolerance to the Roundup ${ }^{\circledR}$ family of agricultural herbicides. This study evaluated the variability of CP4 EPSPS expression using an enzyme-linked immunosorbent assay in soybean tissues collected across diverse germplasm and 74 different environments in Argentina, Brazil and the USA. Evaluated material included single and combined (stacked) trait products with other GE traits in entries with cp4 epsps gene at one or two loci. The highest level of CP4 EPSPS was observed in leaf tissues, intermediate in forage and seed, and lowest in root tissues. Varieties with two loci had approximately twice the level of CP4 EPSPS expression compared to one locus entries. Variable and non-directional level of CP4 EPSPS was observed with other factors like genetic background,
\end{abstract}

Parimala Chinnadurai and Duška Stojšin have contributed equally to this work.

Electronic supplementary material The online version of this article (https://doi.org/10.1007/s11248-018-0092-z) contains supplementary material, which is available to authorized users.

P. Chinnadurai · D. Stojšin $\cdot$ K. Liu $\cdot$ G.

E. Frierdich - K. C. Glenn - T. Geng - A. Schapaugh ·

K. Huang · A. E. Deffenbaugh ( $\square)$.

Z. L. Liu · L. A. Burzio

Bayer Crop Sciences, 700 Chesterfield Parkway West,

St. Louis, MO 63017, USA

e-mail: andrew.deffenbaugh@bayer.com trait stacking, growing region or season. The maximum and average CP4 EPSPS expression levels in seed provided large margins of exposure (MOE of approximately 4000 and 11,000, respectively), mitigating concerns over exposure to this protein in food and feed from soybean varieties tolerant to Roundup ${ }^{\circledR}$ herbicides.

Keywords Soybean · Glyphosate-tolerance $\cdot$ CP4 EPSPS · Expression variation · MOE - GE crops

\section{Introduction}

Adoption of transgenic soybean

Since their introduction in 1996, genetically engineered (GE, also referred to as GM or GMO) crops have delivered substantial agronomic, environmental, economic, health and social benefits to both farmers and society at large (ISAAA 2016). The 109-fold increase in acreage of GE crops during the 1996-2016 period of their commercialization is indicative of the benefits realized by both large and small farmers worldwide. In 2016 , as much as $78 \%$ of soybean acres were planted with GE varieties resulting in the highest adoption rate of GE crops globally (ISAAA 2016). These varieties include products with both single and stacked GE traits. In 2016, herbicide-tolerant soybean 
was planted on 68 million ha, whereas varieties with stacked transgenes (herbicide-tolerance and insectprotected traits) were grown on 23.4 million ha worldwide (ISAAA 2016). As more GE traits become available to farmers, the proportion of varieties with stacked transgenes will become more prevalent.

Roundup Ready ${ }^{\mathrm{TM}}$ herbicide tolerant GE traits have been widely cultivated for over 20 years. Roundup Ready ${ }^{\mathrm{TM}}$ soybean exhibit tolerance to glyphosate, the active ingredient of the Roundup ${ }^{\circledR}$ family of agricultural herbicides. Roundup Ready ${ }^{\mathrm{TM}}$ varieties contain a gene derived from a naturally-occurring soil microbe, Agrobacterium sp. strain CP4 that encodes the cp4 epsps gene that confers tolerance to glyphosate. Fiveenolpyruvylshikimate-3-phosphate synthase (EPSPS), an enzyme from the shikimate pathway, catalyzes the reversible reaction of phosphoenolpyruvate (PEP) and 5-hydroxyl of shikimate-3-phosphate (S3P) to form EPSP and phosphate (Padgette et al. 1995).

\section{Safety of CP4 EPSPS}

The food and feed safety of the proteins produced by GE crops are assessed using a two-tiered, weight-ofevidence approach (Delaney et al. 2008; Codex Alimentarius 2009; Hammond et al. 2013). The first tier provides a weight of the evidence to support protein safety by assessing: history of safe use, bioinformatics analysis, mode of action, in vitro digestibility, heat stability, expression level and dietary intake (Delaney et al. 2008). Based on the first-tier assessment, no hazard was identified for CP4 EPSPS (Harrison et al. 1996; Nair et al. 2002). This first-tier data included: (1) bioinformatic analysis showing no significant structural similarities between CP4 EPSPS and proteins associated with allergy or toxicity, and (2) susceptibility of CP4 EPSPS to rapid degradation by both pepsin and pancreatin, supporting a conclusion that this protein is unlikely to be allergic or toxic and that no meaningful exposure to intact CP4 EPSPS will occur through ingestion of food or feed from crops expressing this protein (Harrison et al. 1996).

On a case-by-case basis, confirmatory second tier of testing can be used to further assess the potential for mammalian toxicity using an appropriate animal model (e.g., in vivo toxicology study). Even though no hazard was identified in the first-tier assessment, an acute toxicity study with mice was conducted with CP4 EPSPS for further safety assurance. No adverse effects were observed when mice received an acute dose of $572 \mathrm{mg} / \mathrm{kg}$ body weight by oral gavage, a dose much higher than anticipated human exposures from foods potentially containing the CP4 EPSPS.

Variability of protein expression

Both conventional and GE crops are typically tested across a large number of environments, and those that show superior results and performance stability are brought to market (Privalle et al. 2012; Prado et al. 2014; Glenn et al. 2017). For GE crops, additional comprehensive assessment of potential food, feed and environmental risks are completed prior to commercialization as part of requirements by global regulatory agencies (Cellini et al. 2004; König et al. 2004; EFSA 2006; Paoletti et al. 2008; Codex Alimentarius 2009; Hoekenga et al. 2013). As part of this risk assessment both the potential hazard of the introduced protein, as well as the exposure is evaluated. The assessment of exposure is in part based on protein expression levels and factors that might influence this variation.

It has been reported that the protein expression levels (endogenous and GE) are highly variable depending on genotypic (Trtikova et al. 2015) and environmental factors (Nguyen and Jehle 2007; Jamal et al. 2009). Genotypic factors that influence variation in protein expression can be associated with the genes controlling the protein or the genetic makeup of the plant. A large number of genes are present in multiple copies throughout genome (Stranger et al. 2007; Springer et al. 2009; Zheng et al. 2011) and this variation has been associated with differences in expression levels (Stranger et al. 2007; Springer et al. 2009). Increased copy number of a gene can correlate with protein expression levels either positively (Gendloff et al. 1990; Hobbs et al. 1990, 1993; Falco et al. 1995; James et al. 2002; Halfhill et al. 2003; Stranger et al. 2007) or negatively (Hobbs et al. 1990, 1993; James et al. 2002; Stranger et al. 2007). Furthermore, protein expression often varies in different plant tissues (Padgette et al. 1995; Down et al. 2001; Nguyen and Jehle 2007; Gampala et al. 2017; Matthews et al. 2017). Even the same plant tissue sampled at different days or developmental stages may show differences in expression (Gendloff et al. 1990; Down et al. 2001; Nguyen and Jehle 2007; Matthews et al. 2017). 
In addition to genotypic factors, the environment can influence the expression of both endogenous and GE proteins. Environmental conditions (e.g., temperature, light, water availability, nutrients, environmental stresses) associated with different seasonal and geographical variables have been shown to impact plant growth and development influencing protein expression (Down et al. 2001; Heck et al. 2005; Nguyen and Jehle 2007; Jamal et al. 2009; Trtikova et al. 2015; Gampala et al. 2017; Geng et al. 2017). Plant-to-plant variation within the same genetic background has been observed (Down et al. 2001; Nguyen and Jehle 2007) as even subtle environmental differences can influence variation in protein expression (Raser and O'Shea 2005).

The objectives of this study were: (1) to evaluate the variability of CP4 EPSPS expression in different soybean tissues collected across diverse germplasm grown in Argentina, Brazil and the USA, (2) to use variance component analysis to identify the factors that affect CP4 EPSPS expression, (3) to assess if the observed variability substantially impacts estimates of food and feed exposure to CP4 EPSPS and risk assessment endpoints like margins of exposure (MOE) and (4) to demonstrate the redundancy of the protein expression data required for global regulatory approvals of the products containing the cp4 epsps transgene.

\section{Materials and methods}

Field trials

The tissue-specific expression of CP4 EPSPS used in this study was generated across 14 different field trials: two in Argentina, seven in Brazil and five in the USA (S-Table 1). The trials were conducted across nine seasons (from 2007 to 2014/2015) and 22 states/ provinces representing a total of 74 environments (10 in Argentina, 33 in Brazil and 31 in the USA) in regions suitable for commercial soybean production. All 14 field trials were planted using a randomized complete block design. The trials conducted in 2007 in the USA and in 2007/2008 in Argentina had three replications, whereas all the other field trials had four replications. These trials were selected for this study because the protein expression data associated with them were submitted to global regulatory agencies in support of import or cultivation approvals of products containing the cp4 epsps transgene.

Soybeans grown across the 14 trials were of different maturity groups (ranging from MG 3 to MG 9) depending on the region of adaptation. All the varieties grown in the USA belonged to MG 3-4, whereas those grown in Argentina and Brazil had a wider range of maturity groups (MG 3-6 and MG 5-9, respectively). The entries considered in this study were Roundup Ready ${ }^{\mathrm{TM}}$ soybeans that exhibit tolerance to the Roundup ${ }^{\circledR}$ family of agricultural herbicides (Monsanto Company, St. Louis, MO, USA). In addition to the glyphosate-tolerance trait, some entries were stacked with other transgenes: insect-protected traits, nutritionally-enhanced traits and/or other herbicide-tolerance traits (S-Tables 1, 2). The glyphosate-tolerance trait was stacked with one, two or three other GE traits making two-way, three-way, or fourway stacks, respectively. Most of the entries evaluated in this study (91\%) contained the cp4 epsps gene at one locus, whereas two trials (USA 2009 and Argentina 2013/2014) included a stacked product that contained cp4 epsps gene at two loci (originating from MON 89,788 and MON 87,705) (S-Table 2). All CP4 EPSPS entries were treated with Roundup ${ }^{\circledR}$ herbicide at the prescribed rate during the season.

Plant tissue samples were collected throughout the season from early development at V3 to full maturity at R8 stage (Pedersen 2004). Leaf samples (leaf 1, leaf 2 , leaf 3 and leaf 4 ) represented the youngest fully expanded trifoliates collected at four developmental stages V3-V5, V4-V9, R1-R3 and R3-R6, respectively. The root samples were collected at the R6 stage and were thoroughly washed of soil. The forage samples represented the whole above ground plant (including stems, leaves and pods) at the R6 stage. The leaf, root and forage tissues were collected and stored on dry ice within 30 min of sample collection. Seed was harvested at maturity (R8) and kept at ambient temperature prior to preparation for analysis.

\section{ELISA for CP4 EPSPS}

Soybean tissue samples were ground in a grinder for approximately $1 \mathrm{~min}$. The CP4 EPSPS was extracted from about $100 \mathrm{mg}$ of each ground soybean tissue by using a Harbil Mixer (Fluid Management, Inc, Wheeling, IL, USA) with about $10 \mathrm{ml}$ (1-100 tissue to buffer ratio was determined to be optimal) of 
trisborate buffer consisting of $0.1 \mathrm{M}$ Tris, $0.1 \mathrm{M} \mathrm{Na}_{2-}$ $\mathrm{B}_{4} \mathrm{O}_{7}, 0.005 \mathrm{M} \mathrm{MgCl}_{2}, 0.05 \%$ (v/v) Tween20 and $0.2 \%$ (w/v) L-ascorbic acid (pH 7.8). Insoluble material was removed from soybean tissue extract using a $16 \mathrm{~mm} \times 4^{\prime \prime}$ serum filter (Cat. No.: 02-681-51, Fisher Scientific, Pittsburgh, PA, USA). The tissue extracts were stored at $-80{ }^{\circ} \mathrm{C}$ until analysis.

An enzyme-linked immunosorbent assay (ELISA) was developed and validated for the detection of CP4 EPSPS. Quantification of CP4 EPSPS was accomplished by interpolation from the logistic curve-fits of the purified CP4 EPSPS standard. The protein standard was produced by fermentation of E. coli. The protein standard (97\% purity by sodium dodecyl sulfate polyacrylamide gel electrophoresis and densitometric analysis) was stored in a buffer solution containing $50 \mathrm{mM}$ Tris-Cl, $\mathrm{pH} 7.5,25 \%$ (v/v) glycerol, $50 \mathrm{mM} \mathrm{KCl}$ and $2 \mathrm{mM}$ DTT. The identity of the protein was confirmed by $\mathrm{N}$-terminal sequencing using 15 automated cycles of Edman degradation chemistry (Hunkapiller et al. 1983), and peptide mass fingerprint analysis (64\% coverage) using MALDITOF mass spectrometry. The specific activity of the enzyme was 4.86 Units/mg CP4 EPSPS based on a spectrophotometric assay for released inorganic phosphate (Lanzetta et al. 1979). For the CP4 EPSPS ELISA, the antibody sandwich (capture antibody from mouse) was detected with goat anti-CP4 EPSPS horseradish peroxidase conjugate followed by development with horseradish peroxidase substrate and the enzymatic reaction was terminated by the addition of $6 \mathrm{M} \mathrm{H}_{3} \mathrm{PO}_{4}$. A buffer blank, a negative control and a positive control were also included on every ELISA plate. Positive control was GE soybean tissue extract that contained CP4 EPSPS and the negative control was conventional soybean tissue extract. All ELISA plates were analyzed on a SPECTRAmax Plus 384 (Molecular Devices, Sunnyvale, CA) microplate spectrophotometer, using a dual wavelength (450 and $620 \mathrm{~nm}$ as reference) detection method. For all data that was greater than or equal to the limit of quantification, the amount of CP4 EPSPS was estimated by interpolation from the standard curve and the level in the tissues was calculated on a $\mu \mathrm{g} / \mathrm{g}$ fresh weight (fw) basis. The moisture content was measured using a moisture analyzer system (Mettler-Toledo, LLC, Columbus, OH, USA) and was used to convert the fresh weight value of to dry weight of the CP4
EPSPS expression. This conversion was done considering tissue moisture levels obtained for each tissue type at each location.

\section{Margin of exposure (MOE)}

A margin of exposure is calculated by dividing the value for no observed adverse effect level (NOAEL) obtained from an appropriate toxicology study by the estimated intake value of the evaluated substance (Eaton and Gilbert 2008).

The MOEs for this protein were calculated by dividing the highest tested dose from an acute toxicity study with CP4 EPSPS in which no adverse effect was noted (Harrison et al. 1996) by the estimated CP4 EPSPS intake value. The acute study is considered an appropriate surrogate for food safety of this protein because toxic proteins tend to act acutely (Sjoblad et al. 1992; Hammond and Fuchs 1998; Pariza and Johnson 2001). The protein intake value used to calculate a MOE was obtained by multiplying CP4 EPSPS expression levels ( $\mu \mathrm{g} / \mathrm{g}$ fresh weight) in soybean seed by soybean consumption data (USDA 2017). Fresh weight expression values were calculated by multiplying the dry weight protein expression by a correction factor of 0.898 to account for an average $10.2 \%$ moisture content in the soybean seed harvested in these trials. The MOE values were calculated based on the overall average and the maximum CP4 EPSPS expression values across all field trials.

\section{Statistical methods}

Statistical analysis was conducted using ELISA results from a total of 3989 soybean tissue samples. The SAS procedure PROC MEANS was used to calculate sample mean, standard deviation and standard error for target variables (SAS 2012). The_ENREF_1 differences among the levels for each of target variable were evaluated at the 5\% significance level.

The following linear mixed models were used for estimation of genotypic variables including cp4 epsps locus number (one or two), soybean maturity groups (MG 3-4, MG 5-6 or MG 8-9), singles versus stacks, number of GE traits (2-way, 3-way or 4-way stack) and the type of GE traits in stacks (herbicidetolerance, insect-protection or nutritionallyenhanced): 
Locus number:

$$
\begin{aligned}
\mathrm{Y}_{\mathrm{ijklm}}= & \mu+\mathrm{M}_{\mathrm{i}}+\mathrm{T}(\mathrm{M})_{\mathrm{j}(\mathrm{i})}+\mathrm{E}_{\mathrm{k}}+\mathrm{M} * \mathrm{E}_{\mathrm{ik}} \\
& +\mathrm{E}^{*} \mathrm{~T}(\mathrm{M})_{\mathrm{kj}(\mathrm{i})}+\varepsilon_{\mathrm{ijklm}}
\end{aligned}
$$

where $Y_{\mathrm{ijklm}}$ is the CP4 EPSPS expression of locus number $\mathrm{i}$, trait $\mathrm{j}$, field trial $\mathrm{k}$, location 1 and observation $\mathrm{m} ; \mu$ is the overall mean; $\mathrm{M}_{\mathrm{i}}$ is the fixed effect of the ith locus number; $\mathrm{T}(\mathrm{M})_{\mathrm{j}(\mathrm{i})}$ is the fixed effect of the jth trait nested within the ith locus number; $\mathrm{E}_{\mathrm{k}}$ is the random effect of the kth location; $M * E_{i k}$ is the random effect of the interaction between the ith locus number and the lth location; $\mathrm{E} * \mathrm{~T}(\mathrm{M})_{\mathrm{kj}(\mathrm{i})}$ is the random effect of the interaction between the kth field trial and jth trait nested within the ith locus number; and $\varepsilon_{\mathrm{ijklm}}$ is the residual error.

Maturity group:

$$
\begin{aligned}
\mathrm{Y}_{\mathrm{ijklm}}= & \mu+\mathrm{M}_{\mathrm{i}}+\mathrm{T}_{\mathrm{j}}+\mathrm{M} * \mathrm{~T}_{\mathrm{ij}}+\mathrm{S}_{\mathrm{k}}+\mathrm{E}(\mathrm{S})_{1(\mathrm{k})}+\mathrm{M} \\
& * \mathrm{E}(\mathrm{S})_{\mathrm{il}(\mathrm{k})}+\mathrm{T} * \mathrm{E}(\mathrm{S})_{\mathrm{jl}(\mathrm{k})}+\varepsilon_{\mathrm{ijklm}}
\end{aligned}
$$

where $\mathrm{Y}_{\mathrm{ijklm}}$ is the CP4 EPSPS expression of maturity group $\mathrm{i}$, trait $\mathrm{j}$, field trial $\mathrm{k}$, location 1 and observation $\mathrm{m} ; \mu$ is the overall mean; $\mathrm{M}_{\mathrm{i}}$ is the fixed effect of the ith maturity group; $T_{j}$ is the fixed effect of the jth trait; $M * T_{i j}$ is the random effect of the interaction between the ith maturity group and the jth trait; $S_{\mathrm{k}}$ is the random effect of the kth field trial; $E(S)_{1(\mathrm{k})}$ is the random effect of the lth location nested within the kth field trial; $\mathrm{M}^{*} \mathrm{E}(\mathrm{S})_{\mathrm{il}(\mathrm{k})}$ is the random effect of the interaction between the ith maturity group and the lth location nested within the kth field trial; $\mathrm{T} * \mathrm{E}(\mathrm{S})_{\mathrm{jl}(\mathrm{k})}$ is the random effect of the interaction between the jth trait and the lth location nested within the kth field trial; and $\varepsilon_{\mathrm{ijklm}}$ is the residual error.

Singles versus stacks:

$$
\begin{aligned}
\mathrm{Y}_{\mathrm{ijklm}}= & \mu+\mathrm{M}_{\mathrm{i}}+\mathrm{T}(\mathrm{M})_{\mathrm{j}(\mathrm{i})}+\mathrm{S}_{\mathrm{k}} \\
& +\mathrm{E}(\mathrm{S})_{1(\mathrm{k})}+\mathrm{M} * \mathrm{E}(\mathrm{S})_{\mathrm{il}(\mathrm{k})}+\mathrm{T} * \mathrm{E}(\mathrm{S})_{\mathrm{jl}(\mathrm{k})}+\varepsilon_{\mathrm{ijklm}}
\end{aligned}
$$

where $Y_{i j k l m}$ is the CP4 EPSPS expression of trait number (i.e., single or stack) i, trait $\mathrm{j}$, field trial $\mathrm{k}$, location 1 and observation $\mathrm{m}$; $\mu$ is the overall mean; $\mathrm{M}_{\mathrm{i}}$ is the fixed effect of the ith trait number; $T(M)_{j(i)}$ is the random effect of the jth trait nested within the ith trait number; $S_{k}$ is the random effect of the kth field trial; $E(S)_{1(\mathrm{k})}$ is the random effect of the lth location nested within the kth field trial; $\mathrm{M}^{*} \mathrm{E}(\mathrm{S})_{\mathrm{il}(\mathrm{k})}$ is the random effect of the interaction between the ith trait number and the lth location nested within the kth field trial; $\mathrm{T} * \mathrm{E}(\mathrm{S})_{\mathrm{j}(\mathrm{k})}$ is the random effect of the interaction between the jth trait and the lth location nested within the kth field trial; and $\varepsilon_{\mathrm{ijklm}}$ is the residual error.

Number of GE traits in stacks:

$$
\begin{aligned}
\mathrm{Y}_{\mathrm{ijklm}}= & \mu+\mathrm{M}_{\mathrm{i}}+\mathrm{T}(\mathrm{M})_{\mathrm{j}(\mathrm{i})}+\mathrm{S}_{\mathrm{k}} \\
& +\mathrm{E}(\mathrm{S})_{1(\mathrm{k})}+\mathrm{M} * \mathrm{E}(\mathrm{S})_{\mathrm{il}(\mathrm{k})}+\mathrm{T} * \mathrm{E}(\mathrm{S})_{\mathrm{jl}(\mathrm{k})}+\varepsilon_{\mathrm{ijklm}}
\end{aligned}
$$

where $Y_{i j k l m}$ is the CP4 EPSPS expression of trait number $\mathrm{i}$, trait $\mathrm{j}$, field trial $\mathrm{k}$, location $\mathrm{l}$ and observation $\mathrm{m} ; \mu$ is the overall mean; $\mathrm{M}_{\mathrm{i}}$ is the fixed effect of the ith trait number; $\mathrm{T}(\mathrm{M})_{\mathrm{j}(\mathrm{i})}$ is the random effect of the $\mathrm{jth}$ trait nested within the ith trait number; $S_{k}$ is the random effect of the kth field trial; $E(S)_{1(k)}$ is the random effect of the lth location nested within the kth field trial; $\mathrm{M} * \mathrm{E}(\mathrm{S})_{\mathrm{il}(\mathrm{k})}$ is the random effect of the interaction between the ith trait number and the lth location nested within the kth field trial; $\mathrm{T} * \mathrm{E}(\mathrm{S})_{\mathrm{jl}(\mathrm{k})}$ is the random effect of the interaction between the jth trait and the lth location nested within the kth field trial; and $\varepsilon_{\mathrm{ijklm}}$ is the residual error.

GE trait type:

$$
\begin{aligned}
\mathrm{Y}_{\mathrm{ijklm}}= & \mu+\mathrm{M}_{\mathrm{i}}+\mathrm{T}(\mathrm{M})_{\mathrm{j}(\mathrm{i})}+\mathrm{S}_{\mathrm{k}}+\mathrm{E}(\mathrm{S})_{1(\mathrm{k})}+\mathrm{M} \\
& * \mathrm{E}(\mathrm{S})_{\mathrm{il}(\mathrm{k})}+\mathrm{T} * \mathrm{E}(\mathrm{S})_{\mathrm{jl}(\mathrm{k})}+\varepsilon_{\mathrm{ijklm}}
\end{aligned}
$$

where $\mathrm{Y}_{\mathrm{ijklm}}$ is the CP4 EPSPS expression of trait type $\mathrm{i}$, trait $\mathrm{j}$, field trial $\mathrm{k}$, location 1 and observation $\mathrm{m} ; \mu$ is the overall mean; $M_{i}$ is the fixed effect of the ith trait type; $\mathrm{T}(\mathrm{M})_{\mathrm{j}(\mathrm{i})}$ is the random effect of the $\mathrm{jth}$ trait nested within the ith trait type; $S_{k}$ is the random effect of the kth field trial; $\mathrm{E}(\mathrm{S})_{1(\mathrm{k})}$ is the random effect of the lth location nested within the $k$ th field trial; $\mathrm{M} * \mathrm{E}(\mathrm{S})_{\mathrm{il}(\mathrm{k})}$ is the random effect of the interaction between the ith trait type and the lth location nested within the kth field trial; $\mathrm{T}^{*} \mathrm{E}(\mathrm{S})_{\mathrm{jl}(\mathrm{k})}$ is the random effect of the interaction between the jth trait and the lth location nested within the kth field trial; and $\varepsilon_{\mathrm{ijklm}}$ is the residual error.

The following linear mixed models were used for estimation of environmental variables (country and season):

Country:

$$
\begin{aligned}
\mathrm{Y}_{\mathrm{ijkl}}= & \mu+\mathrm{M}_{\mathrm{i}}+\mathrm{T}_{\mathrm{j}}+\mathrm{M} * \mathrm{~T}_{\mathrm{ij}} \\
& +\mathrm{E}(\mathrm{M})_{\mathrm{k}(\mathrm{i})}+\mathrm{T} * \mathrm{E}(\mathrm{M})_{\mathrm{jk}(\mathrm{i})}+\varepsilon_{\mathrm{ijk} \mathrm{l}}
\end{aligned}
$$


where $\mathrm{Y}_{\mathrm{ijkl}}$ is the CP4 EPSPS expression of country $\mathrm{i}$, trait $\mathrm{j}$, location $\mathrm{k}$ and observation $\mathrm{l} ; \mu$ is the overall mean; $M_{i}$ is the fixed effect of the ith country; $T_{j}$ is the fixed effect of the jth trait; $M * T_{i j}$ is the random effect of the interaction between the ith country and the jth trait; $\mathrm{E}(\mathrm{M})_{\mathrm{k}(\mathrm{i})}$ is the random effect of the kth location nested within the ith country; $\mathrm{T} * \mathrm{E}(\mathrm{M})_{\mathrm{jk}(\mathrm{i})}$ is the random effect of the interaction between the jth trait and the kth location nested within the ith country; and $\varepsilon_{\mathrm{ijkl}}$ is the residual error.

Season:

$$
\begin{aligned}
\mathrm{Y}_{\mathrm{ijk}}= & \mu+\mathrm{M}_{\mathrm{i}}+\mathrm{T}_{\mathrm{j}}+\mathrm{M}^{*} \mathrm{~T}_{\mathrm{ij}} \\
& +\mathrm{E}(\mathrm{M})_{\mathrm{k}(\mathrm{i})}+\mathrm{T} * \mathrm{E}(\mathrm{M})_{\mathrm{jk}(\mathrm{i})}+\varepsilon_{\mathrm{ijk} l}
\end{aligned}
$$

where $Y_{\mathrm{ijkl}}$ is the CP4 EPSPS expression of season $\mathrm{i}$, trait $\mathrm{j}$, location $\mathrm{k}$ and observation $\mathrm{l} ; \mu$ is the overall mean; $M_{i}$ is the fixed effect of the ith season; $T_{j}$ is the fixed effect of the jth trait; $M * T_{i j}$ is the random effect of the interaction between the ith season and the jth trait; $\mathrm{E}(\mathrm{M})_{\mathrm{k}(\mathrm{i})}$ is the random effect of the kth location nested within the ith season; $\mathrm{T}^{*} \mathrm{E}(\mathrm{M})_{\mathrm{jk}(\mathrm{i})}$ is the random effect of the interaction between the jth trait and the kth location nested within the ith season; and $\varepsilon_{\mathrm{ijkl}}$ is the residual error.

\section{Variance component analysis}

Variance component analysis (VCA) was used to assess the amount of variation in CP4 EPSPS expression that is associated with key genotypic and environmental variables. The following random effects model was used:

$Y=\mu+\mathrm{G}+\mathrm{E}+\mathrm{G} * \mathrm{E}+\varepsilon$,

where $\mathrm{Y}$ is the CP4 EPSPS expression, $\mu$ is the overall mean, $G$ is set of genotypic variables, $E$ is a set of environmental variables, $\mathrm{G} * \mathrm{E}$ is the interaction between genotypic and environmental variables and $\varepsilon$ is residual error. SAS PROC MIXED was used to estimate the covariance parameters for all random effects appearing in the model. The variance component parameters for all effects (genotypic, environmental and genotypic by environmental) were divided by the total variance to get the variance proportion for each.

\section{Results and discussion}

The efficacy of the cp4 epsps gene that confers tolerance to glyphosate across commercial Roundup $\operatorname{Ready}^{\mathrm{TM}}$ varieties has been uniform and consistent (Nair et al. 2002). The efficacy of the cp4 epsps gene for varieties used in this study was verified by treating the plots with Roundup ${ }^{\circledR}$ herbicide. No plant injury or mortality was observed in any of the treated plots (data not shown) which indicated the efficacy of cp4 epsps gene and that the protein is being expressed correctly.

The assessment of CP4 EPSPS expression was based on robust data collected across diverse genetic and environmental factors. The level of CP4 EPSPS expression was evaluated in a total of 3989 Roundup Ready ${ }^{\mathrm{TM}}$ soybean samples. Four plant tissues were collected (i.e., leaf at different development stages, root, forage and seed) from diverse glyphosate-tolerant GE varieties. All varieties contained the cp4 epsps gene either as a single product or stacked with one, two or three other GE traits (S-Table 1). The stacked products included entries where the cp4 epsps gene was combined with other herbicide-tolerance (MON 87708), insect-protected (MON 87701, MON 87751) and/or nutritionally-enhanced (MON 87705, MON $87769)$ traits (S-Tables 1, 2). Most of the entries had cp4 epsps gene at one locus, but some had it at two loci (when both MON89788 and MON 87705 were included). Samples were collected from 14 different field trials in Argentina, Brazil and the USA representing diverse locations across 22 states/provinces. The trials were conducted over nine seasons (2007-2014/2015), totaling 74 different environmental conditions. Soybean varieties were adapted to these different regions and ranged from MG 3 to MG 9. This diversity of genetic and environmental factors provided an opportunity for a very comprehensive evaluation of CP4 EPSPS expression and factors that may influence it.

\section{Genotypic factors}

Several genotypic sources of variation in CP4 EPSPS expression were considered in this research. Some were associated with the GE traits like number of $c p 4$ epsps loci, number and type of stacked GE traits. Others were associated with genetic factors like tissue type (which will have differential patterns of 
expression unique to each tissue) or diverse soybean varieties included in these field trials.

The number of copies of a gene can influence expression levels (Hobbs et al. 1990, 1993; James et al. 2002; Halfhill et al. 2003; Stranger et al. 2007; Springer et al. 2009) and may result in differences associated with phenotypic characteristics like disease resistance in soybean (Cook et al. 2012) or heterosis in maize (Springer et al. 2009). In this study, all field trials included entries that contained a single cp 4 epsps locus, whereas two field trials also included entries with two cp4 epsps loci. Entries containing two cp4 epsps loci had higher protein expression that tended to show approximately twice the expression observed for those containing a single cp4 epsps locus across all tissue types (S-Fig. 1). This is in agreement with those studies that show positive correlation between gene copy number and expression levels (Gendloff et al. 1990; Falco et al. 1995; Halfhill et al. 2003). The same researchers also point out that this correlation can be negative for some genes or events. Thus, our results regarding the additive gene action associated with $c p 4$ epsps is applicable for evaluated events, but cannot be extrapolated to other traits.

Even though the differences in expression between entries with one and two cp4 epsps loci were significant, tolerance to Roundup ${ }^{\circledR}$ herbicide applications that followed label requirements was observed across all trials and for all CP4 EPSPS entries regardless of locus number.

To provide tolerance to Roundup ${ }^{\circledR}$ herbicide, the CP4 EPSPS is expressed throughout the plant and across developmental stages. Previous studies showed variation in protein expression associated with different plant tissues (Padgette et al. 1995; Down et al. 2001; Nguyen and Jehle 2007; Gampala et al. 2017; Matthews et al. 2017) and different developmental stages (Gendloff et al. 1990; Down et al. 2001; Nguyen and Jehle 2007). In our research, for a single locus entries, no significant difference in CP4 EPSPS expression was observed among leaf tissues collected at four different stages of plant development (i.e., V3V5, V4-V9, R1-R3 and R3-R6) with the mean values ranging from 254.4 to $290.7 \mu \mathrm{g} / \mathrm{g}$ (S-Fig. 1). The lowest CP4 EPSPS expression for single locus entries was detected for root tissue $(54.4 \mu \mathrm{g} / \mathrm{g})$, whereas the values for forage and seed tissues were similar (157.4 and $123.5 \mu \mathrm{g} / \mathrm{g}$, respectively), but were both significantly lower compared to those observed for leaf tissue. These results are similar to previously reported studies on CP4 EPSPS expression (Padgette et al. 1995; Nair et al. 2002; Heck et al. 2005; Gampala et al. 2017).

Similar trends for the relative expression levels in different tissues were observed for entries with two cp4 epsps loci. Numerically, leaf tissues had the highest CP4 EPSPS expression (ranging from 436.5 to $650.6 \mu \mathrm{g} / \mathrm{g})$, followed by forage $(340.2 \mu \mathrm{g} / \mathrm{g})$, seed $(207.1 \mu \mathrm{g} / \mathrm{g}$ ) and root tissue averaging $126.5 \mu \mathrm{g} / \mathrm{g}$ (SFig. 1). Most of the leaf comparisons were not significantly different, with the exception of leaf 1 which had significantly lower expression values than leaf 4.

Factors associated with genetic background can be evaluated as potential sources of variation for protein expression (Trtikova et al. 2015; Geng et al. 2017). Varieties considered in this study were grouped into three maturity clusters ranging from MG 3 (adapted to temperate climate) to MG 9 (adapted for tropics). This wide range represents genetic diversity of tested entries, as the varieties of different maturity were developed in different breeding programs within the regions of adaptation. No significant differences in CP4 EPSPS expression were observed among the three maturity clusters for any of the tissue types except for leaf 3 where MG 8-9 had significantly lower CP4 EPSPS expression (Table 1). Similar results were obtained when analysis was conducted for soybean varieties included in this study (data not shown). This indicates that genetic background of different varieties or the time required to reach plant maturity were not important contributors to variability of CP4 EPSPS expression. This observation that genetic background and maturity of soybean varieties do not significantly impact variability in expression of CP4 EPSPS is comparable with results from studies where expression of several non-transgenic soybean proteins was evaluated (Geng et al. 2017).

With development of new GE traits, the adoption of stacked products in the marketplace steadily increases across crops. In Brazil, for example, soybean varieties with herbicide-tolerance stacked with insect-protected trait increased from 2.2 million ha in 2013/2014 season to 20.2 million ha in 2015/2016 (ISAAA 2016). In our study, some of the entries contained only the cp4 epsps gene (single GE trait), whereas others had the cp4 epsps gene stacked with one, two or three different GE traits (S-Tables 1, 2). Comparisons 
Table 1 Comparisons for genotypic factors and their effect on single locus CP4 EPSPS expression $(\mu \mathrm{g} /$ $\mathrm{g} \mathrm{dw})$

NS not significant differences

${ }^{\mathrm{a}}$ Means within a column for each genotypic factor followed by different letters are significantly different at 0.05 significance level:

*significant differences

\begin{tabular}{|c|c|c|c|c|c|c|c|}
\hline Genotypic factors & Leaf 1 & Leaf 2 & Leaf 3 & Leaf 4 & Root & Forage & Seed \\
\hline \multicolumn{8}{|l|}{ Maturity groups } \\
\hline MG 3-MG 4 & 238.2 & 287.8 & $306.5 \mathrm{a}$ & 275.7 & 53.3 & 168.8 & 109.8 \\
\hline MG 5-MG 6 & 289.4 & 288.7 & $258.8 \mathrm{a}$ & 309.0 & 50.5 & 139.5 & 138.4 \\
\hline MG 8-MG 9 & 247.2 & 274.4 & $204.8 b$ & 263.5 & 62.6 & 147.5 & 137.2 \\
\hline Differences $^{\mathrm{a}}$ & NS & NS & $*$ & NS & NS & NS & NS \\
\hline \multicolumn{8}{|c|}{ Single versus stacks with other GE traits } \\
\hline cp4 epsps single & 263.2 & 304.1 & 287.8 & 342.5 & 79.0 & 169.4 & 152.9 \\
\hline cp4 epsps stacks & 259.6 & 279.7 & 264.7 & 258.0 & 42.8 & 149.8 & 108.6 \\
\hline Differences $^{\mathrm{a}}$ & NS & NS & NS & NS & NS & NS & NS \\
\hline \multicolumn{8}{|c|}{ Number of GE traits in stacks } \\
\hline 2-Way stack & 243.5 & 294.3 & 249.1 & 249.5 & 43.5 & 126.1 & 107.4 \\
\hline 3-Way stack & 276.6 & 261.8 & 350.9 & 261.1 & 64.5 & 214.5 & 130.8 \\
\hline 4-Way stack & 284.3 & 331.1 & 350.9 & 283.9 & 21.7 & 181.7 & 116.9 \\
\hline Differences $^{\mathrm{a}}$ & NS & NS & NS & NS & NS & NS & NS \\
\hline \multicolumn{8}{|c|}{ Type of GE traits in stacks } \\
\hline Herbicide-tolerance & 230.0 & 268.6 & 219.9 & 225.9 & 34.3 & 107.2 & 98.7 \\
\hline Insect-protection & 309.2 & 302.2 & 297.2 & 267.4 & 45.8 & 162.4 & 118.1 \\
\hline Nutritionally-enhanced & 212.4 & 246.0 & 227.9 & 243.7 & 46.5 & 148.0 & 115.2 \\
\hline Differences $^{\mathrm{a}}$ & NS & NS & NS & NS & NS & NS & NS \\
\hline
\end{tabular}

between single and stacked GE products indicated that there were no significant differences in CP4 EPSPS expression levels for any of the evaluated tissue types (Table 1). Furthermore, no significant differences were observed among stacked products regardless of number of GE traits for any of the evaluated tissues. Generally, our data indicated that the presence of the other transgene(s) did not influence the CP4 EPSPS expression levels. Similarly, others showed comparable results between single and stacked products for soybean, maize and cotton products they evaluated (Gampala et al. 2017).

Entries stacked with cp4 epsps gene evaluated in this study included three types of GE traits (tolerance to dicamba herbicide, insect-protection and traits that provide nutritional enhancement). There were no differences in CP4 EPSPS expression observed among these three groups of stacked products for any of the tissue types (Table 1) indicating that cp4 epsps gene did not interact with a transgene that provides similar function (i.e., dicamba herbicide-tolerance), nor with those that provide different functions (i.e., insectprotection and nutritionally-enhanced traits).

\section{Environmental factors}

When protein expression is evaluated in different seasons and/or locations (Nair et al. 2002; Nguyen and Jehle 2007; Geng et al. 2017), it provides an opportunity to assess the potential influence of environmental factors on expression levels. In our study, the field testing was conducted in 4-8 locations per trial, from the 2007 to the $2014 / 2015$ growing season, representing a diverse range of environmental conditions across North and South American regions where soybean is typically grown. The trials were conducted in three countries: Argentina, Brazil and the USA, with two trials grown in Argentina, seven in Brazil and five in the USA. These diverse regions are associated with climate conditions ranging from continental to tropical. Despite this geographic diversity, significant differences were detected for expression levels only in leaf 3 tissue across countries, with no differences for the other leaf tissues, root, forage and seed tissues (Table 2). Despite this lack of significant differences, the high variability of CP4EPSPS expression within each region is noteworthy for the evaluated tissues (Fig. 1).

Similar analysis was performed across nine growing seasons. Most included a single field trial with the 
Table 2 Comparisons for environmental factors and their effect on single locus CP4 EPSPS expression $(\mu \mathrm{g} /$ $\mathrm{g} \mathrm{dw})$

NS not significant differences

${ }^{\mathrm{a}}$ Means within a column for each environmental factor followed by different letters are significantly different at 0.05 significance level:

* significant differences;

${ }^{\mathrm{b}}$ See S-Table 1 for information on the specific geography associated with the data for specific seasons

\begin{tabular}{llllllll}
\hline Environment & Leaf 1 & Leaf 2 & Leaf 3 & Leaf 4 & Root & Forage & Seed \\
\hline Countries & & & & & & & \\
Argentina & 410.1 & 301.6 & $255.7 \mathrm{ab}$ & 337.1 & 38.0 & 124.7 & 111.4 \\
Brazil & 225.9 & 268.5 & $220.6 \mathrm{~b}$ & 266.3 & 63.3 & 125.0 & 127.9 \\
USA & 241.5 & 293.8 & $330.8 \mathrm{a}$ & 286.9 & 54.9 & 182.7 & 128.1 \\
Differences $^{\mathrm{a}}$ & $\mathrm{NS}$ & $\mathrm{NS}$ & $*$ & NS & NS & NS & NS \\
Seasons $^{\mathrm{b}}$ & & & & & & & \\
2007 & $248.7 \mathrm{~b}$ & 265.9 & $304.1 \mathrm{~b}$ & 239.9 & 40.7 & $119.8 \mathrm{c}$ & 103.8 \\
$2007 / 2008$ & $369.3 \mathrm{a}$ & 322.2 & $203.1 \mathrm{c}$ & 344.4 & 41.0 & $119.1 \mathrm{c}$ & 116.1 \\
$2008 / 2009$ & $207.0 \mathrm{~b}$ & 196.7 & $233.8 \mathrm{bc}$ & 337.1 & - & $263.0 \mathrm{ab}$ & 144.9 \\
2009 & $186.8 \mathrm{~b}$ & 332.5 & $258.1 \mathrm{bc}$ & 334.1 & 66.6 & $159.8 \mathrm{c}$ & 129.8 \\
$2009 / 2010$ & $196.2 \mathrm{~b}$ & 182.6 & $203.8 \mathrm{bc}$ & 168.7 & - & - & - \\
$2012 / 2013$ & $304.1 \mathrm{ab}$ & 362.4 & $282.8 \mathrm{bc}$ & 291.6 & 66.1 & $156.3 \mathrm{bc}$ & 145.5 \\
2013 & $299.1 \mathrm{ab}$ & 267.9 & $455.1 \mathrm{a}$ & 277.9 & 62.7 & $273.2 \mathrm{a}$ & 167.7 \\
$2013 / 2014$ & $245.9 \mathrm{~b}$ & 264.5 & $237.2 \mathrm{bc}$ & 258.1 & 40.6 & $180.8 \mathrm{bc}$ & 90.1 \\
$2014 / 2015$ & $273.5 \mathrm{ab}$ & 300.5 & $253.5 \mathrm{bc}$ & 291.5 & - & $104.2 \mathrm{c}$ & 151.9 \\
Differences & $*$ & NS & $*$ & NS & NS & $*$ & NS \\
\hline
\end{tabular}
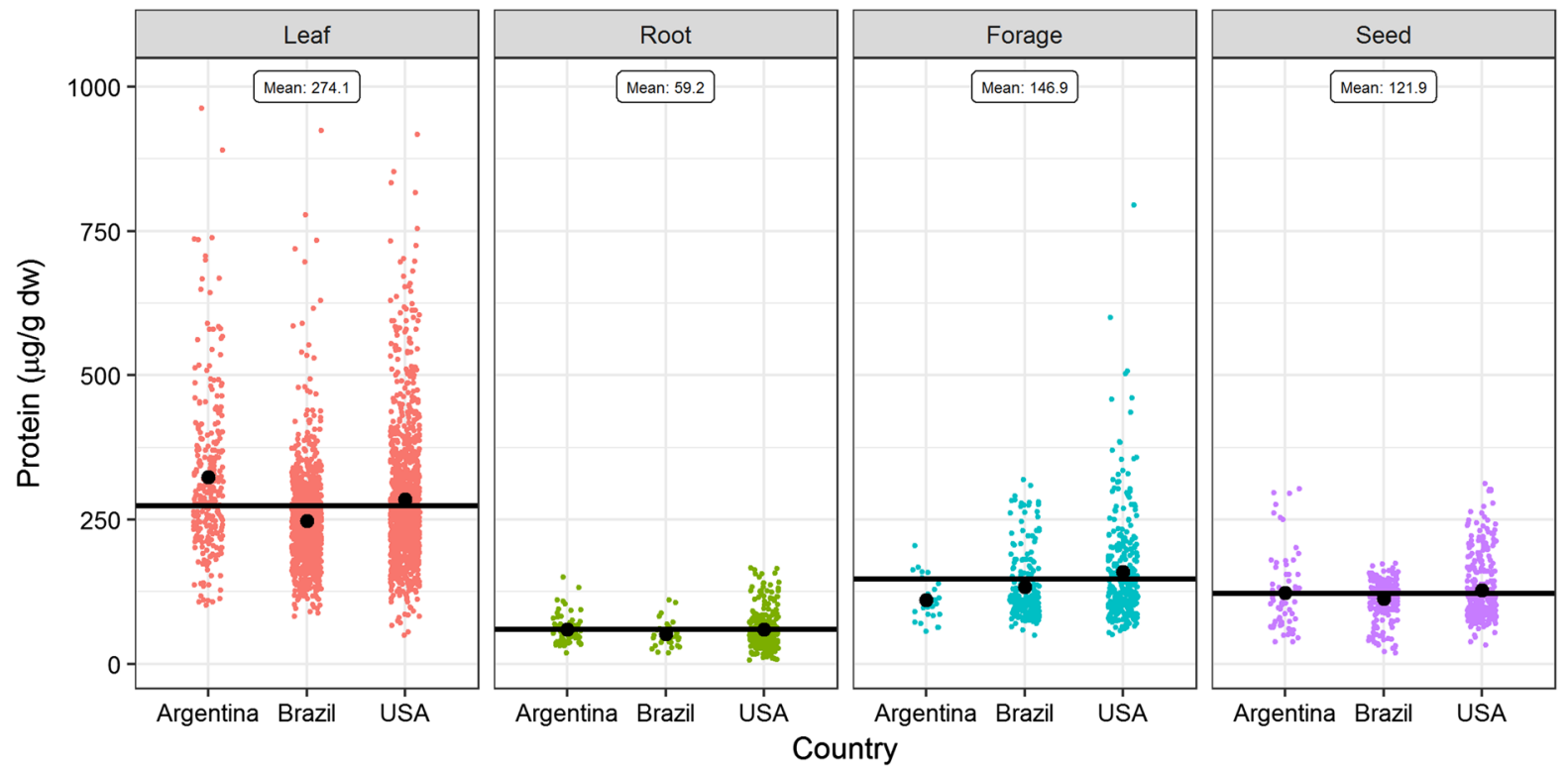

Fig. 1 Variation of single locus CP4 EPSPS expression $(\mu \mathrm{g} /$ $\mathrm{g} \mathrm{dw}$ ) observed for different growing regions. Each dot represents a data point of CP4 EPSPS expression from either

exception of 2007, 2009 and 2012/2013 seasons which were represented by two trials each (S-Table 1). Generally, high variability in CP4 EPSPS expression was observed for some of the growing seasons (Fig. 2), with statistically significant differences observed for leaf 1 , leaf 3 and forage tissue types (Table 2).
Argentina, Brazil or the United States, whereas the horizontal line indicates mean value per tissue type. The leaf data represents all growth stages of leaf analyzed

Variance component analysis

Variance component analysis was used to assess the amount of variation in CP4 EPSPS expression that is associated with key genotypic and environmental variables. The analysis indicated that two genotypic components that contributed the most were cp4 epsps 

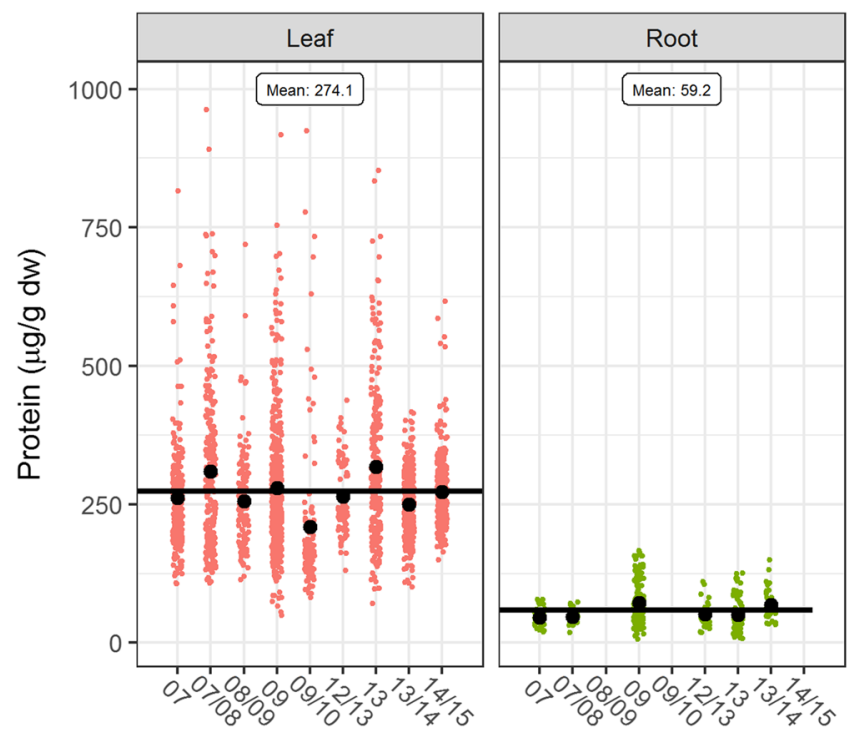
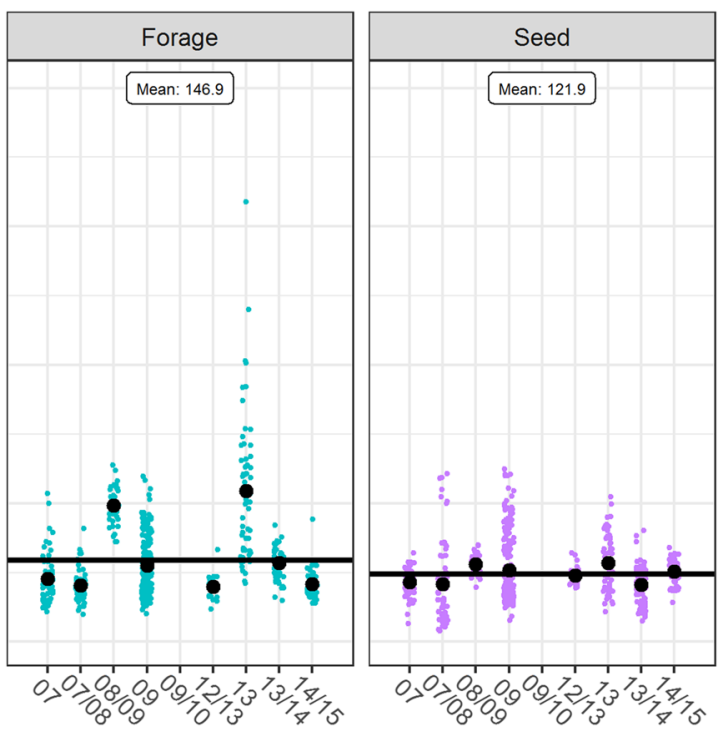

Season

Fig. 2 Variation of single locus CP4 EPSPS expression $(\mu \mathrm{g} /$ $\mathrm{g} \mathrm{dw}$ ) observed for different growing seasons. Each dot represents a data point of CP4 EPSPS expression from either 2007, 2007/2008, 2008/2009, 2009, 2009/2010, 2012/2013,

locus number and tissue type, whereas genetic background and maturity of soybean varieties, as well as the stacking cp4 epsps gene with other biotechnology traits contributed to a lesser extent.

When two major sources of genotypic variation were removed from the analysis (e.g., the variance components for single locus entries by tissue types), the results showed that environmental variation contributed to $19.5-52.5 \%$ of the variation depending on the tissue (Fig. 3). Most of the environmental variation was observed for forage and seed tissues, whereas the least was detected for root tissue. Similarly, others have analyzed transgene expression by tissue types and found that environmental factors contributed the most to protein variation (Gampala et al. 2017). The variation observed in our study is most likely attributable to different abiotic/biotic conditions at each testing environment, as well as micro-environmental conditions within each plot (Raser and O'Shea 2005).

Therefore, some level of environmental variation is expected in any field study as there is variability in meteorological and agronomical factors that cannot be completely eliminated. However, these field trials are designed to control for many of the environmental factors that might influence the crop development
$20132013 / 2014$ or 2014/2015 season, whereas the horizontal line indicates mean value per tissue type. The leaf data represents all growth stages of leaf analyzed

(e.g., water, nutrition, protection against weeds, insects and diseases) and thus the variation of protein expression. Results generated in these well-designed trials have been used for assessing food, feed and environmental risks, not only in regions where the trials were conducted, but were applicable to other countries/regions. Consequently, duplicated testing in different world areas, sometimes required by regulatory agencies, is not scientifically justified.

\section{Safety of CP4 EPSPS}

For proteins expressed in GE crops, safety assessments include an evaluation of hazard potential (e.g., toxicity) and may also include a risk assessment, that places the hazard assessment data in the context of anticipated exposures to the protein (Codex Alimentarius 2009). No hazards have been identified for CP4 EPSPS (Hammond et al. 1996; Harrison et al. 1996; Hammond and Cockburn 2008), therefore, a further assessment of risk is not needed from a scientific standpoint because there is no risk in the absence of hazard (risk $=$ hazard $\times$ exposure). However, estimating the MOE provides further context to enable leveraging the hazard characterization data in an overall risk assessment of CP4 EPSPS. The MOE is 


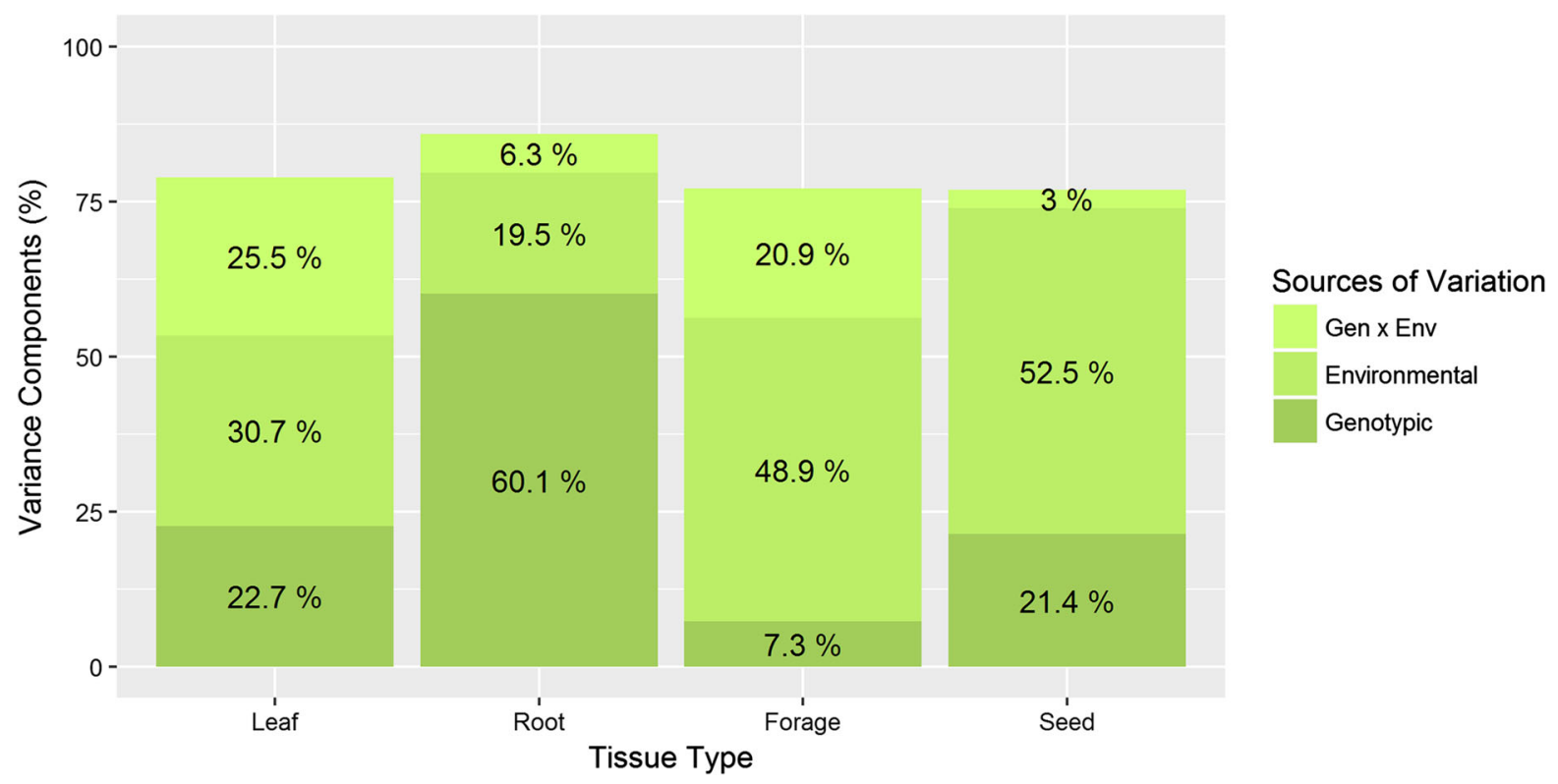

Fig. 3 Variance component analysis of single locus CP4 EPSPS expression by tissue types considering environmental, genotypic and genotypic $\times$ environmental sources of variation

calculated as a ratio between the highest tested dose from an appropriate toxicity study with the protein at which no adverse effect was noted and a conservative estimate of human dietary exposure to the protein (protein intake) (Eaton and Gilbert 2008). As CP4 EPSPS expression varies due to environmental or genotypic factors, the MOE estimate will reflect these varying expression values. Conservative estimates are used for exposure assessment (e.g., 100\% market penetration/full replacement with evaluated trait, no loss of protein during processing) so that a gross overestimate of human exposure is ensured. Full replacement represents an unrealistic exposure scenario and protein exposure assessments reflect significant overestimates because dietary protein exposure tends to be significantly reduced by the harsh conditions of food processing or cooking (Hammond and Jez 2011). Therefore, slight differences in CP4 EPSPS expression (due to genetic or environmental factors) do not fundamentally change the safety conclusion based on the observed lack of hazard in the toxicological assessment and the robust safety margins that demonstrate no meaningful risk to humans from dietary exposure to proteins produced in GE plants.

The appropriate MOE threshold for drawing safety conclusions from dietary exposure to proteins has not been established, but based on the paradigm for toxic chemicals, the traditional approach is to use a minimum of a 100-fold MOE to estimate the level of exposure to an agent that would be assumed to not adversely impact human health (Faustman and Omenn 2008). This 100 -fold MOE accounts for inter-species and inter-individual variability. An even more conservative approach is to include an additional 10-fold safety factor to account for other uncertainties such as sensitive subpopulations or a limited toxicology database resulting in a very conservative MOE of 1000. There are three variables (dose level, protein expression and consumption) that can impact the MOE and by either increasing or decreasing one or more of these variables, the MOE will get larger or smaller. Since the focus of this study was variation of CP4 EPSPS expression, the acute non-toxic dose level of $572 \mathrm{mg} / \mathrm{kg}$ body weight (Harrison et al. 1996) and soybean consumption of $2.0 \mathrm{~g} / \mathrm{kg}$ body weight/day (USDA 2017) were kept constant and only the protein expression variable was adjusted to illustrate the modest differences in MOE values associated with changes in protein expression levels in glyphosatetolerant soybean across the broad dataset used in this study.

The evaluation of CP4 EPSPS expression in soybean seed across different environments illustrates the inherent variability associated with protein 
expression in GE crops. The maximum value of $\mathrm{CP} 4$ EPSPS expression in soybean seed observed in this study was $343.5 \mu \mathrm{g} / \mathrm{g}$ dry weight with an overall mean value of $124 \mu \mathrm{g} / \mathrm{g}$ dry weight across all field trials representing 74 environments, different number of $c p 4$ epsps loci and different trait combinations. The estimated MOE values were approximately 4000 and 11,000 for the maximum and average CP4 EPSPS expression values, respectively. These MOE values are about 4 and 11 times higher than the highly conservative approach of providing adequate human health protection with a MOE of 1,000 for toxic chemicals, whereas CP4 EPSPS is a readily digestible protein unlikely to survive food processing conditions. It can therefore be concluded that the observed variations in CP4 EPSPS expression do not impact the overall safety of GE crop products expressing this protein, because empirical data provide MOE values that are sufficiently large to adequately protect human health. These results apply across GE crop products and are consistent with the conclusion that the overall weight of evidence indicates clearly that evaluated GE products can be used safely in food and feed production (Hammond and Cockburn 2008).

In summary, extensive testing of CP4 EPSPS expression levels was conducted across different soybean tissues collected from field trials grown in 74 diverse environments. Two genotypic factors that contributed to significant differences in expression levels in the plant were number of cp4 epsps loci and the type of plant tissue tested. Genotypic factors like genetic background or maturity of soybean varieties tested, stacking the cp4 epsps gene with one or more transgenes, or the function of the stacked trait(s) did not significantly impact the CP4 EPSPS expression. Generally, environmental conditions like regions and seasons did not have consistent impact on the level of CP4 EPSPS expression for the evaluated tissue types as non-directional variability was observed. These results are informative for evaluations of products containing cp4 epsps transgene as they indicate that: (1) Within each experimental factor (locus number, tissue type, genetic background, number of GE traits, type of GE traits, region and season), CP4 EPSPS expression can be highly variable. (2) Across environmental factors (regions and seasons), variability of CP4 EPSPS expression was not significant or directional. The country or region where the crop is grown is not expected to be important for risk assessment associated with GE protein expression. (3) Stacking cp4 epsps with one or more GE traits (e.g., different herbicide-tolerance, insect-protected and/or nutritionally-enhanced traits) did not impact CP4 EPSPS expression. (4) The CP4 EPSPS expression was affected by cp4 epsps locus number in a predictable manner. (5) CP4 EPSPS expression levels in the tested tissues showed differences that were consistent across samples from a wide range of environmental field conditions. (6) Product efficacy has been demonstrated with a range of expression values. (7) Variability of CP4 EPSPS expression does not materially affect the MOE calculations that consistently estimate negligible risk associated with consumption of CP4 EPSPS. Product safety has been demonstrated despite variability in CP4 EPSPS expression, as demonstrated by vary large MOEs, thereby making a single trait MOE determination applicable to risk assessments for combined trait products. (8) The protein expression data required for global regulatory approvals of any product containing the cp4 epsps transgene, including stacks, is extensive and safety and characterization conclusions on protein expression can be derived using more focused data sets.

The research summarized in this report contributes a large data set that comprehensively describes the effect of several genetic and environmental factors on the variation in expression of an introduced protein, CP4 EPSPS, found in many GE crops (single and combined trait). Importantly, both the safety and the efficacy of this introduced protein that provides glyphosate tolerance, are each not affected by the variability in protein expression, ensuring that consumers can trust the safety of their food and farmers can rely and benefit from the trait efficacy.

Acknowledgements We wish to thank Bayer teams in Argentina, Brazil and the USA for coordinating and conducting field trials, the protein expression team for generating CP4 EPSPS expression data and those who helped with data and manuscript review: T. Armstrong, A. Beyene, J. Colyer, C. Doyle, S. Franklin, S-W. Hoi, M. Jose, T. Lee, S. Levine, K. Levis, D. Mahadeo, S. Mozaffar, S. Nolte, W. Oliveira, J. Petrick, M. Scarco, P. Sisson, D. Soares, J. Vicini and $\mathrm{H}$. Vertuan.

Open Access This article is distributed under the terms of the Creative Commons Attribution 4.0 International License (http:// creativecommons.org/licenses/by/4.0/), which permits unrestricted use, distribution, and reproduction in any medium, provided you give appropriate credit to the original 
author(s) and the source, provide a link to the Creative Commons license, and indicate if changes were made.

\section{References}

Cellini F, Chesson A, Colquhoun I, Constable A, Davies HV, Engel KH, Gatehouse AMR, Kärenlampi S, Kok EJ, Leguay J-J, Lehesranta S, Noteborn HPJM, Pedersen J, Smith M (2004) Unintended effects and their detection in genetically modified crops. Food Chem Toxicol 42(7):1089-1125

Codex Alimentarius (2009) Foods derived from modern biotechnology, 2nd edn. Rome, Italy, Codex Alimentarius Commission, Joint FAO/WHO Food Standards Programme, Food and Agriculture Organization of the United Nations

Cook DE, Lee TG, Guo X, Melito S, Wang K, Bayless AM, Wang J, Hughes TJ, Willis DK, Clemente TE, Diers BW, Wang J, Hudson ME, Bent AF (2012) Copy number variation of multiple genes at Rhg1 mediates nematode resistance in soybean. Sci Mag 338:1206-1209

Delaney B, Astwood JD, Cunny H, Conn RE, Herouet-Guicheney C, MacIntosh S, Meyer LS, Privalle L, Gao Y, Mattsson J, Levine M (2008) Evaluation of protein safety in the context of agricultural biotechnology. Food Chem Toxicol 46:S71-S97

Down RE, Ford L, Bedford SJ, Gatehouse LN, Newell C, Gatehouse JA, Gatehouse AMR (2001) Influence of plane development and environment on transgene expression in potato and consequence for insect resistance. Transgenic Res 10:223-236

Eaton DL, Gilbert SG (2008) Principles of toxicology. In: Klaassen CD (ed) Casarett and Doull's toxicology-the basic science of poisons. McGraw-Hill, Inc, New York, pp 11-43

EFSA (2006) Guidance document for the risk assessment of genetically modified plants and derived food and feed by the scientific panel on genetically modified organisms (GMO) - including draft document updated in 2008. EFSA J 4:99. https://doi.org/10.2903/j.efsa.2006.99

Falco SC, Guida T, Mauvais J, Locke M, Ward RT, Webber P (1995) Transgenic canola and soybean seeds with increased Lysine. Bio Technol 13:577-582

Faustman EM, Omenn GS (2008) Risk assessment. In: Klassen $\mathrm{CD}$ (ed) Casarett and Doull's toxicology-the basic science of poisons. McGraw-Hill, New York, pp 107-128

Gampala SS, Fast BJ, Richey KA, Gao Z, Hill R, Wulfkuhle B, Shan G, Bradfisch GA, Herman RA (2017) Single-event transgene product levels predict levels in genetically modified breeding stacks. J Agric Food Chem 65(36):7885-7892

Gendloff EH, Bowen B, Buchholz WG (1990) Quantitation of choramphenicol acetyl transferase in transgenic tobacco plants. Plant Mol Biol 14:575-583

Geng T, Stojsin D, Liu K, Schaalje B, Postin C, Ward J, Wang Y, Liu LZ, Li B, Glenn K (2017) Natural variability of allergen levels in conventional soybeans: assessing variation across north America and south America from five production years. J Agric Food Chem 65:463-472

Glenn KC, Alsop B, Bell E, Goley M, Jenkinson J, Liu B, Martin C, Parrot W, Souder C, Sparks O, Urquhart W, Ward JM, Vicini JL (2017) Bringing new plant varieties to market: plant breeding and selection practices advance beneficial characteristics while minimizing unintended changes. Crop Sci 57:2906-2921

Halfhill MD, Millwood RJ, Weissinger AK, Warwick SI, Stewart CN (2003) Additive transgene expression and genetic introgression in multiple green-fluorescent protein transgenic crop $\times$ weed hybrid generations. Theor Appl Genet 107(8):1533-1540

Hammond BG, Cockburn A (2008) The safety assessment of proteins introduced into crops developed through agricultural biotechnology: a consolidated approach to meet current and future needs. Food safety of proteins in agricultural biotechnology. CRC Press Inc, Boca Raton, pp 259-288

Hammond BG, Fuchs RL (1998) Safety evaluation for new varieties of food crops developed through biotechnology. Biotechnol Saf Assess 19:61-79

Hammond BG, Jez JM (2011) Impact of food processing on the safety assessment for proteins introduced into biotechnology-derived soybean and corn crops. Food Chem Toxicol 49(4):711-721

Hammond BG, Vicini JL, Hartnell GF, Naylor MW, Knight CD, Robinson EH, Fuchs RL, Padgette SR (1996) The feeding value of soybeans fed to rats, chicken, catfish and dairy cattle is not altered by genetic incorporation of glyphosate tolerance. J Nutr 126:717-727

Hammond B, Kough J, Herouet-Guicheney C, Jez JM (2013) Toxicological evaluation of proteins introduced into food crops. Crit Rev Toxicol 43:25-42

Harrison LA, Bailey MR, Naylor MW, Ream JE, Hammond BG, Nida DL, Burnette BL, Nickson TE, Mitsky TA, Taylor ML, Fuchs RL, Padgette SR (1996) The expressed protein in glyphosate-tolerant soybean, 5-enolpyruvylshikimate-3-phosphate synthase from Agrobacterium sp. strain $\mathrm{CP} 4$, is rapidly digested in vitro and is not toxic to acutely gavaged mice. J Nutr 126(3):728-740

Heck GR, Armstrong CL, Astwood JD, Behr CF, Bookout JT, Brown SM, Cavato TA, DeBoer DL, Deng MY, George C, Hillyard JR, Hironaka CM, Howe AR, Jakse EH, Ledesma BE, Lee TC, Lirette RP, Mangano ML, Mutz JN, Qi Y, Rodriguez RE, Sidhu SR, Silvanovich A, Stoecker MA, Yingling RA, You J (2005) Development and characterization of a CP4 EPSPS-based, glyphosate-tolerant corn event. Crop Sci 45(1):329-339

Hobbs SLA, Kpodar P, DeLong CMO (1990) The effect of T-DNA copy number, position and methylation on reporter gene expression in tobacco transformants. Plant Mol Biol 15(6):851-864

Hobbs SLA, Warkentin TD, DeLong CMO (1993) Transgene copy number can be positively or negatively associated with transgene expression. Plant Mol Biol 21(1):17-26

Hoekenga OA, Srinivasan J, Barry G, Bartholomaeus A (2013) Compositional analysis of genetically modified (GM) crops: key issues and future needs. J Agric Food Chem 61(35):8248-8253 
Hunkapiller MW, Hewick RM, Hood LE, Dreyer WJ (1983) High-sensitivity sequencing with gas-phase sequenator. Methods Enzymol 91:399-413

ISAAA (2016) Global status of commercialized biotech/GM crops: ISAAA brief no. 52, Ithaca, New York

Jamal A, Ko K, Kim H-S, Choo Y-K, Joung H, Ko K (2009) Role of genetic factors and environmental conditions in recombinant protein production for molecular farming. Biotechnol Adv 27(6):914-923

James VA, Avart C, Worland B, Snape JW, Vain P (2002) The relationship between homozygous and hemizygous transgene expression levels over generations in populations of transgenic rice plants. Theor Appl Genet 104:553-561

König A, Cockburn A, Crevel RWR, Debruyne E, Grafstroem R, Hammerling U, Kimber I, Knudsen I, Kuiper HA, Peijnenburg AACM, Penninks AH, Poulsen M, Schauzu M, Wal JM (2004) Assessment of the safety of foods derived from genetically modified (GM) crops. Food Chem Toxicol 42(7): 1047-1088

Lanzetta PA, Alvarez LJ, Reinach PS, Candia OA (1979) An improved assay for nanomole amounts of inorganic phosphate. Anal Biochem 100:95-97

Matthews BA, Launis KL, Bauman PA, Juba NC (2017) Double-mutated 5-enol pyruvylshikimate-3-phosphate synthase protein expressed in MZHG0JG Corn (Zea mays L.) has no impact on toxicological safety and nutritional composition. J Agric Food Chem 65(38):8459-8465

Nair RS, Fuchs RL, Schuette SA (2002) Current methods for assessing safety of genetically modified crops as exemplified by data on roundup ready soybeans. Toxicol Pathol 30:117-125

Nguyen HT, Jehle JA (2007) Quantitative analysis of the seasonal and tissue-specific expression of Cry1 Ab in transgenic maize Mon810. J Plant Dis Prot 114:82-87

Padgette SR, Kolacz KH, Delannay X, Re DB, Lavallee BJ, Tinius CN, Rhodes WK, Otero YI, Barry GF, Eichholtz DA, Peschke VM, Nida DL, Taylor NB, Kishore GM (1995) Development, identification, and characterization of a glyphosate-tolerant soybean line. Crop Sci 35(5):1451-1461

Paoletti C, Flamm E, Yan W, Meek S, Renckens S, Fellous M, Kuiper H (2008) GMO risk assessment around the world: some examples. Trends Food Sci Technol 19:S70-S78

Pariza MW, Johnson EA (2001) Evaluating the safety of microbial enzyme preparations used in food processing: update for a new century. Regul Toxicol Pharmacol 33(2): $173-186$

Pedersen P (2004) Soybean growth and development. Iowa State University, Ames

Prado JR, Segers G, Voelker T, Carson D, Dobert R, Phillips J, Cook K, Cornejo C, Monken J, Grapes L, Reynolds T, Martino-Catt S (2014) Genetically engineered crops: from idea to product. Annu Rev Plant Biol 65:769-790

Privalle LS, Chen J, Clapper G, Hunst P, Spiegelhalter F, Zhong CX (2012) Development of an agricultural biotechnology crop production testing from discovery to commercialization. J Agric Food Chem 60:10179-10187

Raser JM, O'Shea EK (2005) Noise in gene expression: origins, consequences, and control. Science 309(5743):2010-2013

SAS (2012) Software release 9.4 (TS1M1). Cary, North Carolina, Copyright 2002-2012 by SAS Institute, Inc

Sjoblad RD, McClintock JT, Engler R (1992) Toxicological considerations for protein components of biological pesticide products. Regul Toxicol Pharmacol 15(1):3-9

Springer NM, Ying K, Fu Y, Ji T, Yeh C-T, Jia Y, Wu W, Richmond T, Kitzman J, Rosenbaum H, Iniguez LA, Barbazuk BW, Jeddeloh JA, Nettleton D, Schnable PS (2009) Maize inbreeds exhibit high levels of copy number variation (cnv) and presence/absence variation (pav) in genome content. PLoS Genet 5(11):1-17

Stranger BE, Forrest MS, Dunning M, Ingle CE, Beazley C, Thorne N, Redon R, Bird CP, Grassi AD, Lee C, TylerSmith C, Carter N, Scherer EW, Tavare S, Panagiotis D, Hurles ME, Dermitzakis ET (2007) Relative impact of nucleotide and copy number variation on gene expression phenotypes. Sci Mag 315:848-853

Trtikova M, Wilmark OG, Zemp N, Widmer A, Hilbeck A (2015) Transgene expression and Bt protein content in transgenic $B t$ maize (MON810) under optimal and stressful environmental conditions. PLoS ONE 10:1-7

USDA (2017) US EPA/USDA dietary exposure evaluation model—food commodity intake database (DEEM-FCID), version 4.01,05-10-c

Zheng L-Y, Guo X-S, He B, Sun L-J, Peng Y, Dong S-S, Liu T-F, Jiang S, Ramachandra S, Liu C-M, Jing H-C (2011) Genome-wide patterns of genetic variation in sweet and grain sorghum (Sorghum bicolor). Genome Biol 12:1-14 